\title{
Targeting Ion Channels: An Important Therapeutic Implication in Gastrointestinal Dysmotility in Patients With Spinal Cord Injury
}

\author{
Miroslav Radulovic, ${ }^{1,2}$ Preeti Anand, ${ }^{3}$ Mark A Korsten, ${ }^{1,2}$ and Bing Gong ${ }^{1,3 *}$ \\ Departments of ${ }^{1}$ Medicine and ${ }^{3}$ Neurology, Icahn School of Medicine at Mount Sinai, New York, NY, USA; and ${ }^{2}$ National Center of Excellence \\ for the Medical Consequences of SCI, James J Peters Veteran Affairs Medical Center, Bronx, NY, USA
}

Gastrointestinal (GI) dysmotility is a severe, and common complication in patients with spinal cord injury (SCl). Current therapeutic methods using acetylcholine analogs or laxative agents have unwanted side effects, besides often fail to have desired effect. Various ion channels such as ATP-sensitive potassium ( $\left.K_{\text {ATP }}\right)$ channel, calcium ions $\left(\mathrm{Ca}^{2+}\right)$-activated potassium ions ( $\mathrm{K}^{+}$) channels, voltage-sensitive $\mathrm{Ca}^{2+}$ channels and chloride ion $\left(\mathrm{Cl}^{-}\right)$channels are abundantly expressed in $\mathrm{Gl}$ tissues, and play an important role in regulating $\mathrm{Gl}$ motility. The release of neurotransmitters from the enteric nerve terminal, innervating $\mathrm{Gl}$ interstitial cells of Cajal (ICC), and smooth muscle cells (SMC), causes inactivation of $\mathrm{K}^{+}$and $\mathrm{Cl}^{-}$channels, increasing Ca ${ }^{2+}$ influx into cytoplasm, resulting in membrane depolarization and smooth muscle contraction. Thus, agents directly regulating ion channels activity either in ICC or in SMC may affect GI peristalsis and would be potential therapeutic target for the treatment of $\mathrm{Gl}$ dysmotility with $\mathrm{SCl}$.

(J Neurogastroenterol Motil 2015;21:494-502)

\section{Key Words}

Dysmotility; Gastrointestinal; Interstitial cells of Cajal; Ion channels; Myocytes, smooth muscle

\section{Introduction}

Gastrointestinal (GI) dysmotility is one of the most common medical complications following spinal cord injury (SCI). Both acute and chronic SCI cause loss of the excitatory neural input to enteric neurons, causing overall lack of neural excitability to the gut, result in constipation, abdominal pain, nausea, bloating, and fecal incontinence, which has significant negative impact on quality of life and increases long-term morbidity. ${ }^{1}$ Currently conventional therapeutic strategies are laxatives, high-fiber diet, cholinergic agonists, mechanical removal of fecal matter. ${ }^{2}$ These methods have obvious inadequacies, although combination therapies are often employed but may fail to have desired effect while causing an increase in adverse effects. For example, chronically using laxatives has been found to be associated with laxative colon

Received: April 12, 2015 Revised: June 10, 2015 Accepted: July 6, 2015

(c) This is an Open Access article distributed under the terms of the Creative Commons Attribution Non-Commercial License (http://creativecommons. org/licenses/by-nc/4.0) which permits unrestricted non-commercial use, distribution, and reproduction in any medium, provided the original work is properly cited.

*Correspondence: Bing Gong, MD Department of Medicine, Icahn School of Medicine at Mount Sinai, One Gustave L. Levy Placc, New York, NY 10029-6574, USA Fax: +1-201-658-3148, E-mail: bing.gong@va.gov

Financial support: This paper is supported by a grant from US Department of Veterans Affairs to Miroslav Radulovic and Mark A Korsten, and by a grant from Alzheimer's Association (IIRG-12-242345) to Bing Gong.

Conflicts of interest: None.

Author contributions: Miroslav Radulovic, Preeti Anand, Mark A Korsten, and Bing Gong wrote this paper. Especially, Mark A Korsten guided the writing in clinical aspects of ion channels in GI dysmotility. 
or colon cancer; chronic mechanical fecal removal is an ordeal for the patient and inconvenient for healthcare workers. Moreover, cholinergic agonists could result in bronchospasm, bronchorrhea, ${ }^{3}$ thereby limiting its use in patients who have chronic obstructive pulmonary disease or suffer from respiratory insufficiency in addition to SCI. Thus studies aimed at finding effective and convenient therapeutic regimen with better adverse effect profile are essential.

Several mechanisms are involved in the causation of GI dysmotility after SCI. These include possible injury to parasympathetic nerve system or motor neuron of enteric nervous system which causes the dysfunctional release of the major regulatory neurotransmitters such as acetylcholine, substance $\mathrm{P}$, etc. This results in a decrease in interstitial cells of Cajal (ICC) activity and diminishes contraction of smooth muscle cells (SMCs) of GI tract, causing the reduction in both nonpropulsive segmental contractions and high amplitude propagating contractions in large intestine. ${ }^{4}$

Ion channels play important roles in the GI motility. Under physiological condition, the release of acetylcholine or substance $\mathrm{P}$ from the parasympathetic post-ganglionic nerve terminal innervating GI smooth muscle inactivates potassium ion $\left(\mathrm{K}^{+}\right)$ channels causing membrane depolarization, and then increasing calcium ions $\left(\mathrm{Ca}^{2+}\right)$ influx into cytoplasm. ${ }^{5}$ The $\mathrm{Ca}^{2+}$ release causes contraction of circular muscle layer, followed by shortening of the longitudinal muscle, thus pushes the bolus of food forward, forming peristaltic wave. ICC are central to the generation and propagation of the cyclical electrical activity while SMCs are responsible for electromechanical coupling. ${ }^{6}$ Recent, evidence shows that abnormal ion channel activities are related to the human GI dysmotility. For example people with mutations in SCN5A have higher prevalence of Brugada syndrome and functional dyspepsia, ${ }^{7}$ as well as irritable bowel syndrome (IBS). ${ }^{8}$ Thus agents directly regulating ion channel activities either in ICC or in SMCs may affect the GI peristalsis. ${ }^{9}$ For example, certain potassium channel blockers and compounds increasing $\mathrm{Ca}^{2+}$ release or $\mathrm{Ca}^{2+}$ sensitivity specifically acting on GI tract would be potentially effective therapeutic agents for GI dysmotility. In this review, we will discuss main groups of ion channels distributed in the GI tract and their potential therapeutic roles in the treatment of GI dysmotility after SCI.

\section{General Electrophysiological Properties of Interstitial Cells of Cajal and Smooth Muscle Cell}

ICC are pacemaker-cells abundantly distributed in stomach, small intestine and colon. ICC are mainly found in the mesenteric plexus which is located deep to muscular plexus close to smooth muscle $^{10}$ forming synapse like junctions with enteric nerve and forming gap junctions with smooth muscle cells. ${ }^{11}$ They generate, and transmit signals from enteric neurons to smooth muscles through the gap junctions (Fig. 1). ${ }^{12}$ Dysfunction of ICC caused by inflammation, mechanic damage or SCI induced enteric nervous dysfunction may result GI paralysis. ${ }^{13}$ The ICC set the basic electric rhythm (slow wave) through establishing the electrochemical equilibrium between the spontaneous depolarizing pacemaker currents and hyperpolarizing $\mathrm{K}^{+}$outward current.

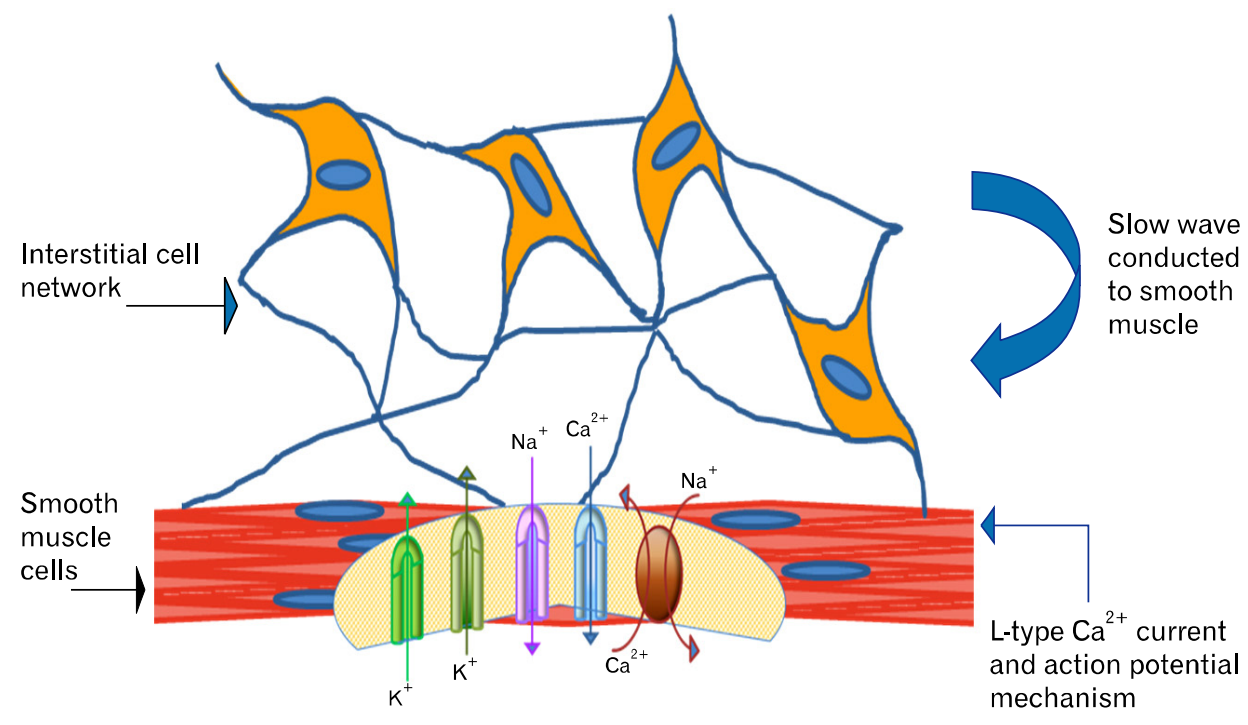

Figure 1. Diagrammatic representation of the interstitial cells of Cajal (ICC) network in the smooth muscle wall of the gastrointestinal (GI) tract. ICC generated slow waves then passed along the waves in the interstitial cell network to the smooth muscle cells, causing the release of $\mathrm{Ca}^{2+}$ into the cytosol, causing muscle contraction and GI peristalsis. 
The inward pacemaker currents in ICC of colon tract have been identified to be $\mathrm{Ca}^{2+}$-activated chloride channels ( $\mathrm{CaCC}$ ) and non-selective cation channels (NSCC). ${ }^{14-16}$ The membrane depolarization caused by the pacemaker currents turns on the T-type $\mathrm{Ca}^{2+}$ channels in the ICC, resulting $\mathrm{Ca}^{2+}$ influx and formation of train action potential. The ICC action potential complex propagates to SMC through the gap junction of interstitial network and initiates the voltage-sensitive calcium ( $\mathrm{Cav}$ ) channels including L-type ( $\left.\mathrm{Ca}_{v} 1\right)$ and T-type $\left(\mathrm{Ca}_{v} 3\right)$ L-type $\mathrm{Ca}^{2+}$ channel in SMC to initiate the excitation-contraction process and causing smooth muscle contraction. ${ }^{17-19}$ The ICC physically closely contact with the varicosities of the enteric nerve, and are sensitive to stretch in addition to a number of enteric neurotransmitters including acetylcholine, adenosine triphosphate, nitric oxide. ${ }^{6}$

Enteric nerve when stimulated by mechanical stretch or chemical signal via afferent neurons, causes GI parasympathetic and motor neurons to release acetylcholine triggering train of action potentials and smooth muscle contraction (Fig. 2). ${ }^{20}$ The frequency of slow-wave sets the rate of muscle movement, while the degree of membrane depolarization or the amount of $\mathrm{Ca}^{2+}$ influx of ICC determines the ionotropicity and contractility of SMC. In patients with SCI, the enteric parasympathetic system is disturbed causing dysregulation of neurotransmitter release, thus resulting GI dysmotility. A wide variety of ion channels has been identified in ICC and SM according their electrophysiological properties, some of these channels play crucial role in the GI motility, thus, we may regulate the GI motility through directly acting on ion channels, the down-stream site of acetylcholine.

\section{Targeting ATP-sensitive Potassium Channel in Interstitial Cells of Cajal}

ATP-sensitive potassium $\left(\mathrm{K}_{\mathrm{ATP}}\right)$ channels are found in a variety of tissues including nervous system, smooth muscles in GI system and pancreatic $\beta$ cells and play crucial physiological roles in these systems. ${ }^{21,22}$ Classical $\mathrm{K}_{\mathrm{ATP}}$ channels are comprised of 2 types of subunits: the pore-forming inwardly rectifying $\mathrm{K}^{+}$channel subunit (Kir6.x), members of Kir channel gene family and regulatory sulfonylurea receptors (SUR1, SUR2A, and SUR2B) members of the ATP-binding cassette superfamily. Genetic disruption of either subunit will lead to dysregulation of smooth muscle, nerve through a heterotrimeric $\mathrm{G}$ protein subunit activated protein kinase $\mathrm{C}(\mathrm{PKC})$ regulated signaling pathway resulting an abnormal activation of L-type $\mathrm{Ca}^{2+}$ channel. ${ }^{23} \mathrm{~K}_{\text {ATP }}$ channel has been identified in ICCs in intestine and colon which is consisted of KIR 6.2 and SUR 2B. Its inward rectifying $\mathrm{K}^{+}$ current sets the resting membrane potential about $-70 \mathrm{mv} .^{24}$ Experiments have showed that one of the mechanisms of acetylcholine promoting GI motility is through an inhibition of $\mathrm{K}_{\mathrm{ATP}}$ channel activity, causing membrane depolarization thus increasing $\mathrm{Ca}^{2+}$ influx in ICC, and increasing the ICC firing frequency. ${ }^{25} \mathrm{~K}_{\text {ATP }}$ channels blockers such as glibenclamide and tolbutamide currently used for the treatment of diabetes through an increase in insulin release have also been shown to increase the rhythm of slow waves and to increase the frequency of the generation of train action potentials of smooth muscles in GI tract. On the other hand, phentolamine, hydrogen sulfide $\left(\mathrm{H}_{2} \mathrm{~S}\right)$, and adenosine, decreases the GI motility by activating $\mathrm{K}_{\mathrm{ATP}}$ channels causing a decrease of intracellular $\mathrm{Ca}^{2+}$ oscillation in ICC and

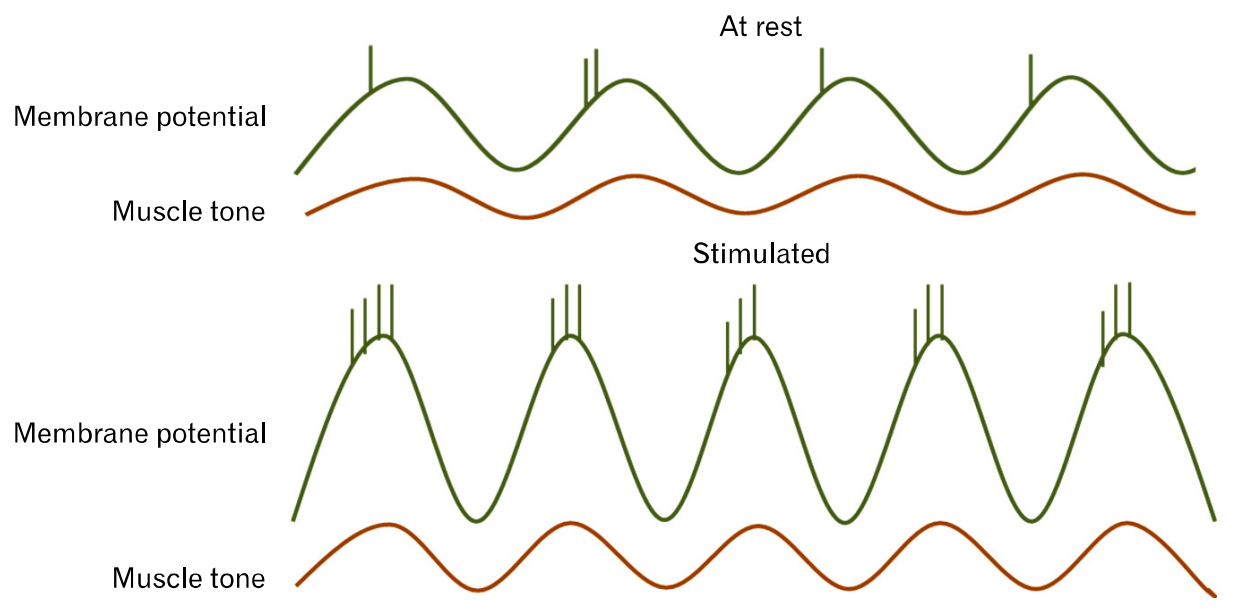

Figure 2. Electrophysiology of gastrointestinal (GI) smooth muscle: excitation coupling in GI smooth muscle. The slow wave will initiate a contraction in smooth muscle when it reaches threshold amplitude to evoke action potentials. The amplitude of the slow wave is altered by release of neurotransmitters from enteric neurons. 
has been used to treat IBS related diarrhea ${ }^{26}$ and this effect was abolished by glibenclamide. Similar to the effects of $K_{\text {ATP }}$ channel in smooth muscle in GI-tract, pinacidil, a specific $\mathrm{K}_{\text {ATP }}$ channel opener has therapeutic effects on mild essential hypertension by relaxing arterial smooth muscle. ${ }^{27}$ Interestingly experiments have showed that activation of $\mathrm{K}_{\mathrm{ATP}}$ channels by prostaglandin E2 (PGE2) through EP2 receptor in cultured ICC from murine small intestine causes smooth muscle relaxation reducing GI motility, hence has been used for the treatment of inflammatory bowel syndrome. ${ }^{28}$ These evidences, although from other systems, support the idea that regulating the activity of $\mathrm{K}_{\mathrm{ATP}}$ channels in ICC could be used to treat the GI dysmotility especially in patients with SCI.

\section{Targeting ATP-sensitive Potassium Channel in Smooth Muscle Cell}

The expression of $\mathrm{K}_{\mathrm{ATP}}$ channel in SMC of GI tract has been identified as co-expression of SUR2B/Kir6.1 or Kir6.2. Increased expression of $\mathrm{K}_{\mathrm{ATP}}$ channel due to inflammation is related to decreased colon motility due to the SMC hyperpolarization. ${ }^{29,30}$ While SUR2B/Kir6.1 is mainly expressed at plasma membrane, the SUR2B/Ki6.2 is mainly located at cytosol of SMC. The regulation of $\mathrm{K}_{\mathrm{ATP}}$ channel is cAMP-PKA/PKC cascade pathway dependent. Certain inhibitory neurotransmitters activate $\mathrm{K}_{\mathrm{ATP}}$ channel through G-protein coupled receptor, by binding with $\mathrm{G} \alpha$ subunit, activate adenyl cyclase, increase cAMP and cause PKA dependent phosphorylation, this results in SMC membrane hyperpolarization, thus reduceing GI motility. ${ }^{31}$ Thus agents which increase the adenylyl cyclase, elevating cyclic AMP including calcitonin gene-related peptide, adenosine and prostacyclin, and specific $\mathrm{K}_{\mathrm{ATP}}$ channel openers (pinacidil and diazoxide); activation of $\mathrm{K}_{\mathrm{ATP}}$ channel in SMC in GI and could be used to reduce the GI motility to treat the IBS related diarrhea. ${ }^{32}$ For example, in antral smooth muscle of guinea-pig cromakalim, diazoxide, and nicorandil cause membrane hyperpolarization by opening $\mathrm{K}_{\mathrm{ATP}}$ channels therefore, reduce the first component and abolish the second component of slow waves. It may be associated with the opening of mitochondrial $\mathrm{K}_{\mathrm{ATP}}$ channel in SMC thus affecting the regulation of $\mathrm{Ca}^{2+}$ handling. Thus evidence suggests that pinacidil and nicorandil may prove useful in providing relief from gastric spasm, while $\mathrm{K}_{\mathrm{ATP}}$ channel inhibitors such as gibenclamide or 5-hydroxydecanoic acid may have therapeutic potential in delayed gastric emptying, as a new type of prokinetic agent. ${ }^{33}$

In the contrary, excitatory neurotransmitters such as acetyl- choline, PKC activator phorbol esters (phorbol 12, 13-dibutyrate) which block $\mathrm{K}_{\mathrm{ATP}}$ channels in GI SMC, cause membrane depolarization, increasing colon/intestinal motility through an activation of PKC. ${ }^{25,31}$ Thus $\mathrm{K}_{\text {ATP }}$ channels blockers such as glibenclamide, tolbutamide, 5-hydroxydecanoic acid, and HMR-1098 $8^{23,34}$ specifically acting on the subtype of channels in SMC may mimic acetylcholine's effects on GI tract while have less non-specific effects on other organs.

\section{$\mathrm{Cl}^{-}$Channel Facilitates ATP-sensitive Potassium Channel Mediated Gastrointestinal Motility}

It has been shown that the spontaneous transient depolarization and spontaneous slow wave in isolated ICC cells can be blocked by niflumic acid, a molecule that specifically inhibits $\mathrm{Cl}^{-}$ channels suggesting that the $\mathrm{Cl}^{-}$channel contributes to the membrane depolarization of ICC. ${ }^{35}$ The major $\mathrm{Cl}^{-}$channel expressed in colon ICC and SMC is a CaCC. It is abundantly expressed in GI smooth muscles; it can be activated by increased intracellular $\mathrm{Ca}^{2+}$ levels and enteric neurotransmitters. The Anoctamin-1 (ANO1) subtype of $\mathrm{CaCC}$ is mainly expressed in ICC, which plays important role in the slow wave generation. Neurokinin-1 has potent effects on the colon contraction could be blocked by the $\mathrm{CaCC}$ blockers such as tamoxifen or chlorotoxin, possibly indicating that effects of Neurokinin-1 on colon are through activation of $\mathrm{Cl}^{-}$channel, and it may have therapeutic potential in the treatment of constipation after SCI. Currently, novel $\mathrm{CaCC}$ opener phenanthroline is being extensively studied, especially in treatment for cystic fibrosis caused by abnormal function of cystic fibrosis transmembrane conductance regulator (CFTR) due to decreased secretion of the $\mathrm{Cl}^{-}$and sodium ion $\left(\mathrm{Na}^{+}\right)$through the $\mathrm{Cl}^{-}$channel of the CFTR in the epithelium. Phenanthroline does not affect the cAMP or intracellular $\mathrm{Ca}^{2+}$ levels, while it activates the $\mathrm{Cl}^{-}$channel, suggesting that it may act directly on the $\mathrm{Cl}^{-}$channels and not through an indirect regulation. Another $\mathrm{Cl}^{-}$ channel activator, lubiprostone which is bicyclic fatty acid derived from PGE1 currently used for the treatment of chronic constipation and constipation predominant IBS. The underlying mechanism is to increase $\mathrm{Cl}^{-}$secretion through $\mathrm{Cl}^{-}$channel increasing $\mathrm{Ca}^{2+}$ influx in gastrointestinal SMC in addition to activating prostaglandin $\mathrm{E}$ receptors (EP1 or $\mathrm{EP} 4)$, thus causing smooth muscle contractions. ${ }^{36,37}$ Hence both lubiprostone and phenanthroline act by activating $\mathrm{Cl}^{-}$channel, causing an increase in $\mathrm{Cl}^{-}$secretion and intestinal fluid or directly enhancing the GI 
tract motility by affecting ICC and SMC activity, these $\mathrm{Cl}^{-}$ channel openers may be an ideal adjunct in the treatment of the GI dysmotility after SCI or in CFTR patients with severe Ileus. Interestingly, $\mathrm{K}_{\mathrm{ATP}}$ channel blockers such as glyburide also increase $\mathrm{Cl}^{-}$channel activity although the main mechanism of action is membrane depolarization caused by the blocking of $\mathrm{K}_{\mathrm{ATP}}$ channel, thus increasing the $\mathrm{Ca}^{2+}$ influx, increasing the SMC contraction. $^{38}$

\section{$\mathrm{Ca}^{2+}$-activated $\mathrm{K}^{+}$Channels}

Small-conductance $\mathrm{Ca}^{2+}$-activated $\mathrm{K}^{+}(\mathrm{SK})$ channels play a role in the regulation of smooth muscle tone in GI tract. SK channels are abundantly distributed in murine proximal colon, three isoforms of SK channels have been identified (SK1, SK2, and SK3). ${ }^{39}$ This channel is responsive to inhibitory neurotransmitters in colonic smooth muscles such as ATP which opens SK channel and causes smooth muscle cell hyperpolarization, mechanistically, reducing the smooth muscle contraction. In human, mutations in the gene encoding the $\mathrm{Ca}_{\mathrm{v}} 2.1 \alpha 1$ subunit of the $\mathrm{P} / \mathrm{Q}$-type voltage-gated calcium channel causes episodic ataxia, a type of inherited movement disorder caused by the reduction in the activity of SK channels. SK channels are activated under basal conditions in colonic smooth muscles contributing to regulation of resting membrane potential, open SK channels maintain membrane hyperpolarization, preventing the activation of $\mathrm{Ca}^{2+}$ channels, causing smooth muscle relaxation. ${ }^{40,41}$ On the other hand, apamin, a peptide neurotoxin extracted from bee venom, blocks SK channels expressed in the GI smooth muscles and causes membrane depolarization $(10 \mathrm{mV})$ and an augmentation of action potentials, thus increases the contractions in colonic muscles. Clotrimazole, an antifungal agent acts by blocking SK channels and has been used to treat myotonic muscular dystrophy and to reduce erythrocyte dehydration in sickle cell anaemia. ${ }^{42,43}$ Some new clotrimazole derivatives have been showed to inhibit the SK channel at colonic endothelia and increases the colon smooth muscle contractility; more recently it has been reported that $\mathrm{H}_{2} \mathrm{~S}$ regulates the ileum contractility through an inhibition of the SK channels, ${ }^{44}$ implying an important therapeutic role of the SK channel inhibitors on GI tract dysmotility.

Large-conductance $\mathrm{Ca}^{2+}$-activated $\mathrm{K}^{+}(\mathrm{BK})$ channel is both voltage- and $\mathrm{Ca}^{2+}$ dependent channel consisting of $4 \alpha$-subunits and four $\beta$-subunits. The $\alpha$-subunits forms the core of the channel which senses the voltage and $\mathrm{Ca}^{2+}$ while the $\beta$-subunits regulate the $\mathrm{Ca}^{2+}$ sensitivity of the channel. In GI smooth muscle, $\beta 1$ subunit is the major subtype modulating the excitation contraction coupling. BK channel is activated by increased $\mathrm{Ca}^{2+}$ spike released by ryanodine receptors, presents on smooth endoplasmic reticulum in SMC. The opening the BK channels increases the $\mathrm{K}^{+}$efflux, shifting the membrane potential to hyperpolarization, deactivating the voltage-dependent $\mathrm{Ca}^{2+}$ influx, thus relaxing smooth muscle or reducing the muscle contractility. ${ }^{45,46}$ There is evidence to prove that smooth muscle specific $\beta 1$ subunit gene knockouts show increased cholinergic-evoked smooth muscle contractions in different organs such as GI tract, urinary bladder, blood vessel and trachea. ${ }^{47-49}$ This process may be regulated through PKC and extracellular signal-regulated kinase signaling pathway. ${ }^{50}$ Evidence shows that bethanechol, a muscarinic cholinergic receptor agonist, induces contractions of the longitudinal muscle in the ileum, proximal and distal colon, promotes colonic motility measured by the fecal output and glass bead expulsion time in presence of $\mathrm{BK}$ channel inhibitor or in $\mathrm{BK} / \beta 1$ channel knockout mice, ${ }^{51,52}$ suggesting that BK channel inhibitors specifically acting on smooth muscles may promote gastric or small intestinal motility, in a functionally similar manner to effects of GI muscarinic cholinergic receptor agonist. Thus the inhibitors of $\mathrm{BK} / \beta 1$ channel in GI smooth muscle such as nitroblue tetrazolium, verapamil, clotrimazole, and other BK channel blockers which are being investigated ${ }^{53}$ may be a potential therapeutic target for the treatment of GI dysmotility after SCI.

\section{Voltage-sensitive $\mathrm{Ca}^{2+}$ Channels}

Two major $\mathrm{Ca}^{2+}$ channels: voltage-sensitive calcium channels L-type and T-type have been found in GI SMCs and ICC. T-type $\mathrm{Ca}^{2+}$ channel is sensitive to mibefradil and low depolarization voltage but resistant to dihydropyridine (DHP) and nefidipine. T-type $\mathrm{Ca}^{2+}$ channel plays important role in the ICCs, causing slow spontaneous depolarization, thus activating pacemaker cells. ${ }^{18}$ L-type $\mathrm{Ca}^{2+}$ channel mainly sensitive to DHP and high voltage stimuli, provides bulk $\mathrm{Ca}^{2+}$ required for the excitation-contraction in SMC and is responsible for contractions. Mutations in genes coding $\mathrm{Ca}^{2+}$ channels in human population cause various diseases such as long QT syndrome, Brugada syndrome, dysphagia, and GI dysmotility. ${ }^{54}$ Animal studies showed that knocking out L-type $\mathrm{Cav} 1.2 \mathrm{Ca}^{2+}$ channel leads to paralytic ileus and colon, causing severe clinical GI consequences. ${ }^{9,55}$

Pharmacologically blocking either L- or T- type $\mathrm{Ca}^{2+}$ channels would cause colon dysmotility, resulting in constipation, a common adverse effect observed in patients on DHP calcium 
channel blocker therapy for hypertension. On the contrary, activating $\mathrm{Ca}^{2+}$ - activated $\mathrm{K}^{+}$channels by trimebutine increases gastric emptying, intestinal and colonic contractility via activation of T-type $\mathrm{Ca}^{2+}$ channel at lower dosage $(1-10 \mu \mathrm{M})$. On the other hand, it has been used for irritable bowel disorders at higher concentration (100-300 $\mu \mathrm{M})$ causing inhibition of L-type $\mathrm{Ca}^{2+}$ channels thus reducing colon peristalsis. ${ }^{56}$ The voltage-sensitive $\mathrm{Ca}^{2+}$ channels in ICC and SMC can be activated by $\mathrm{K}^{+}$channel blockers such as reported potent novel fluoro-oxindoles BMS-204352 and racemic compound 1 which are sensitive to the intracellular $\mathrm{Ca}^{2+}$ levels, ${ }^{57}$ or agents activating $\mathrm{Cl}^{-}$channels as described early in the $\mathrm{K}^{+}$channel section. Moreover, $\mathrm{Ca}^{2+}$ channel openers such as amylin or ryanodine increases $\mathrm{Ca}^{2+}$ influx into the cytosol from sarcoplasmic reticulum, resulting in positive inotropic effect in muscle, which could be a potential target for the treatment of GI dysmotility.

\section{Stretch-dependent $\mathrm{K}^{+}$Channel}

Stretch-dependent $\mathrm{K}^{+}$(SDK) channels abundantly expressed in colonic smooth muscle cells, which encode TWIK-related $\mathrm{K}^{+}$channel (TREK) and TWIK-related arachdonic acid stimulated $\mathrm{K}^{+}$channel (TRAAK) subunits, are sensitive to mechanical stretch, thus causing relaxation in response to smooth muscle elongation produced by contents filling colonic lumen. These are activated by the enteric inhibitory neurotransmitter, nitric oxide mediated cGMP-dependent pathway. ${ }^{58}$ Its major function is to increase the colonic proximal luminal diameter by relaxing GI smooth muscle, during filling to conserve water and electrolytes. This is probably mechanism of action and functionally important for other visceral organs such as uterus and bladder that could be expanded extensively without causing irritable contractions. It has been reported that methionine and its de-

Table. Summarization of Antagonists/Agonists of Ion Channels and Their Effects on Gastrointestinal Motility

\begin{tabular}{|c|c|c|c|c|}
\hline \multirow{2}{*}{ Ion channels } & \multicolumn{2}{|r|}{ Antagonists } & \multicolumn{2}{|r|}{ Agonists } \\
\hline & & Clinical application & & Clinical application \\
\hline $\mathrm{K}_{\text {ATP }}$ channels & $\begin{array}{l}\text { Glibenclamide } \\
\text { Tolbutamide } \\
\text { 5-HAD } \\
\text { HMR-1098 }\end{array}$ & $\begin{array}{l}\text { Diabetes (increasing insulin } \\
\text { release) } \\
\text { GI dysmotility and constipation } \\
\text { (increasing SMC and ICC pulse } \\
\text { frequency) }\end{array}$ & $\begin{array}{l}\text { Phobol-dibutyrate } \\
\text { Cromakalim } \\
\text { Nicorandil } \\
\text { Pinacidil } \\
\text { Diazoxide }\end{array}$ & $\begin{array}{l}\text { IBD and diarrhea } \\
\text { GI track spasm (reducing GI } \\
\text { SMC and ICC pulse frequency) }\end{array}$ \\
\hline $\mathrm{Ca}^{2+}$ activated $\mathrm{K}^{+}$channel & $\begin{array}{l}\text { Apamin } \\
\text { Clotrimazole } \\
\text { Verapamil } \\
\text { Hydrogen sulfide } \\
\text { Trimebutine }\end{array}$ & $\begin{array}{l}\text { Increase the contractions in colonic } \\
\text { smooth muscles (treat } \\
\text { constipation) } \\
\text { Treat myotonic muscle dystrophy }\end{array}$ & & \\
\hline $\begin{array}{l}\mathrm{Ca}^{2+} \text { activated } \mathrm{Cl}^{-} \\
\text {channels }\end{array}$ & $\begin{array}{l}\text { Tamoxifen } \\
\text { Chlorotoxin }\end{array}$ & IBD and diarrhea & $\begin{array}{l}\text { Neurokinin-1 } \\
\text { Phenanthroline } \\
\text { Lubiprostone }\end{array}$ & $\begin{array}{l}\text { Increase GI motility } \\
\text { Treat cystic fibrosis and } \\
\text { constipation } \\
\text { Chronic constipation }\end{array}$ \\
\hline $\begin{array}{l}\text { Voltage-sensitive } \mathrm{Ca}^{2+} \\
\text { channels }\end{array}$ & $\begin{array}{l}\text { Mibefradil } \\
\text { Nefidipine } \\
\text { Nimodipine } \\
\text { Pranidipine } \\
\text { Bepridil }\end{array}$ & $\begin{array}{l}\text { Esophageal spasm } \\
\text { IBS } \\
\text { Mesenteric vascular insufficiency } \\
\text { Dyskinesis of the Sphincter of Oddi } \\
\text { Insulinoma }\end{array}$ & $\begin{array}{l}\text { Amylin } \\
\text { Fluoro-oxindoles } \\
\text { BMS-204352 } \\
\text { Racemic compound } 1 \\
\text { Ryanodine }\end{array}$ & Increase GI motility \\
\hline $\begin{array}{l}\text { Stretch-dependent } \mathrm{K}^{+} \\
\text {channel }\end{array}$ & $\begin{array}{l}\text { Methionine } \\
\text { L-cysteine } \\
\text { L-methionine } \\
\text { DL-homocysteine } \\
\text { Caffeine } \\
\text { Cyclopiazonic acid } \\
\text { Ryanodine }\end{array}$ & $\begin{array}{l}\text { Increase the bladder contractility } \\
\text { Increase GI motility }\end{array}$ & & \\
\hline
\end{tabular}

GI, gastrointestinal; ICC, interstitial cells of Cajal; IBD, inflammatory bowel disorders; IBS, irritable bowel syndrome. 
rivatives increases the bladder contractility by inhibiting stretchdependent $\mathrm{K}^{+}$channel. $^{59}$ The electrophysiological property of the activation of the SDK channel causes membrane hyperpolarization, prevent the activation of the L-type $\mathrm{Ca}^{2+}$ channels in SMC causing GI relaxation. ${ }^{60}$ Pharmacologically, sulfur-containing amino acids, such as L-cysteine, L-methionine, or DLhomocysteine block the SDK channel, cause SMC depolarization and muscle contraction. ${ }^{61}$ Other compounds such as caffeine, ryanodine, and cyclopiazonic acid may also have similar effects. Thus the SDK channel is a another possible target for the treatment of GI dysmotility. Above mentioned compounds effecting on ion channels in GI tract were summarized in Table.

\section{Summary}

GI tract dysmotility is a severe complication after SCI. Currently, treatment for the GI dysmotility mainly consists of acetylcholine agonists which has undesirable side effects, especially among the SCI patients with compromised pulmonary function or bronchial diseases such as asthma and chronic bronchitis. Ion channels have been found to be abundantly distributed in ICC and SMCs of GI tract and play an important physiological role in the regulation of ICC activity and SMC contractility. $\mathrm{K}^{+}$channel blockers (glibenclamide, tolbutamide, $\mathrm{H}_{2} \mathrm{~S}$, nitroblue tetrazolium, fluoro-oxindoles BMS-204352, and 5-HAD), $\mathrm{Cl}^{-}$channel (Neurokinin-1, phenanthroline) and Calcium channel (trimebutine) openers specially act on the GI SMC and ICC could cause membrane depolarization, increasing $\mathrm{Ca}^{2+}$ influx both in ICCs and SMCs, increasing the frequency of excitatory impulses onto smooth muscle, triggering the smooth muscle contraction. The increase in $\mathrm{Ca}^{2+}$ influx, into the cytosol of SMC also directly increases, the smooth muscle contractility, thus promoting bowel movements, and preventing complications caused by constipation. Several drugs targeting ion channels have been applied clinically to treat other diseases, which may have beneficial effects on the GI dysmotility. For example, $\mathrm{K}_{\text {ATP }}$ channel blockers glibenclamide and tolbutamide used in the treatment of Diabetes Mellitus and $\mathrm{CaCC}$ opener phenanthroline used to treat cystic fibrosis cause potent GI smooth muscle contraction and, could be used for the treatment of GI dysmotility. Comparing with the traditional acetylcholine agonists, selective ion channel blockers/openers have specific local effect on the GI tract, thus may serve as potential treatment modality for GI dysmotility with better side effect profile. These compounds acting on various ion channels with specificity for GI tract could be important tools in regulating GI motility and may be answer to complex and distressing problem of GI dysmotility after SCI.

\section{References}

1. Chung EA, Emmanuel AV. Gastrointestinal symptoms related to autonomic dysfunction following spinal cord injury. Prog Brain Res 2006;152:317-333.

2. Bauman WA, Korsten MA, Radulovic M, Schilero GJ, Wecht JM, Spungen AM. Heiner sell lectureship: secondary medical consequences of spinal cord injury. Top Spinal Cord Inj Rehabil 2002; 18:354-378.

3. Coulson FR, Fryer AD. Muscarinic acetylcholine receptors and airway diseases. Pharmacol Ther 2003;98:59-69.

4. Rajendran SK, Reiser JR, Bauman W, Zhang RL, Gordon SK, Korsten MA. Gastrointestinal transit after spinal cord injury: effect of cisapride. Am J Gastroenterol 1992;87:1614-1617.

5. Somlyo AP, Somlyo AV. $\mathrm{Ca}^{2+}$ sensitivity of smooth muscle and nonmuscle myosin II: modulated by $G$ proteins, kinases, and myosin phosphatase. Physiol Rev 2003;83:1325-1358.

6. Sanders KM, Hwang SJ, Ward SM. Neuroeffector apparatus in gastrointestinal smooth muscle organs. J Physiol 2010;588(Pt 23):4621- 4639.

7. Jung KT, Park H, Kim JH, et al. The relationship between gastric myoelectric activity and SCN5A mutation suggesting sodium channelopathy in patients with Brugada syndrome and functional dyspepsia—a pilot study. J Neurogastroenterol Motil 2012;18:58-63.

8. Saito YA, Strege PR, Tester DJ, et al. Sodium channel mutation in irritable bowel syndrome: evidence for an ion channelopathy. Am J Physiol Gastrointest Liver Physiol 2009;296:G211-G218.

9. Beyder A, Farrugia G. Targeting ion channels for the treatment of gastrointestinal motility disorders. Therap Adv Gastroenterol 2012; 5:5-21.

10. Costa M, Dodds KN, Wiklendt L, Spencer NJ, Brookes SJ, Dinning PG. Neurogenic and myogenic motor activity in the colon of the guinea pig, mouse, rabbit, and rat. Am J Physiol Gastrointest Liver Physiol 2013;305:G749-G759.

11. Wang XY, Paterson C, Huizinga JD. Cholinergic and nitrergic innervation of ICC-DMP and ICC-IM in the human small intestine. Neurogastroenterol Motil 2003;15:531-543.

12. Sarna SK. Are interstitial cells of Cajal plurifunction cells in the gut? Am J Physiol Gastrointest Liver Physiol 2008;294:G372-G390.

13. Huizinga JD, Chen JH. Interstitial cells of Cajal: update on basic and clinical science. Curr Gastroenterol Rep 2014;16:363.

14. Burns AJ, Lomax AE, Torihashi S, Sanders KM, Ward SM. Interstitial cells of Cajal mediate inhibitory neurotransmission in the stomach. Proc Natl Acad Sci USA 1996;93:12008-12013.

15. Zhu MH, Kim TW, Ro S, et al. $\mathrm{A} \mathrm{Ca}^{2+}$-activated $\mathrm{Cl}^{-}$conductance in interstitial cells of Cajal linked to slow wave currents and pacemaker activity. J Physiol 2009;587:4905-4918.

16. Gomez-Pinilla PJ, Gibbons SJ, Bardsley MR, et al. Ano1 is a selective marker of interstitial cells of Cajal in the human and mouse gastrointestinal tract. Am J Physiol Gastrointest Liver Physiol 2009; 296:G1370-G1381.

17. Corrias A, Buist ML. A quantitative model of gastric smooth muscle 
cellular activation. Ann Biomed Eng 2007;35:1595-1607.

18. Kim YC, Koh SD, Sanders KM. Voltage-dependent inward currents of interstitial cells of Cajal from murine colon and small intestine. J Physiol 2002;541(Pt 3):797-810.

19. Koh SD, Ward SM, Sanders KM. Ionic conductances regulating the excitability of colonic smooth muscles. Neurogastroenterol Motil 2012;24:705-718.

20. Farrugia G, Lei S, Lin X, et al. A major role for carbon monoxide as an endogenous hyperpolarizing factor in the gastrointestinal tract. Proc Natl Acad Sci USA 2003;100:8567-8570.

21. Standen NB, Quayle JM, Davies NW, Brayden JE, Huang Y, Nelson MT. Hyperpolarizing vasodilators activate ATP-sensitive $\mathrm{K}^{+}$channels in arterial smooth muscle. Science 1989;245:177-180.

22. Mourre C, Widmann C, Lazdunski M. Sulfonylurea binding sites associated with ATP-regulated $\mathrm{K}^{+}$channels in the central nervous system: autoradiographic analysis of their distribution and ontogenesis, and of their localization in mutant mice cerebellum. Brain Res 1990;519:29-43.

23. Rodrigo GC, Standen NB. ATP-sensitive potassium channels. Curr Pharm Des 2005;11:1915-1940.

24. Kito Y, Ward SM, Sanders KM. Pacemaker potentials generated by interstitial cells of Cajal in the murine intestine. Am J Physiol Cell Physiol 2005;288:C710-C720.

25. Nakayama S, Ohya S, Liu HN, et al. Sulphonylurea receptors differently modulate ICC pacemaker $\mathrm{Ca}^{2+}$ activity and smooth muscle contractility. J Cell Sci 2005;118(Pt 18):4163-4173.

26. Ahn SW, Kim SH, Kim JH, et al. Phentolamine inhibits the pacemaker activity of mouse interstitial cells of Cajal by activating ATPsensitive $\mathrm{K}^{+}$channels. Arch Pharm Res 2010;33:479-489.

27. Friedel HA, Brogden RN. Pinacidil. A review of its pharmacodynamic and pharmacokinetic properties, and therapeutic potential in the treatment of hypertension. Drugs 1990;39:929-967.

28. Choi S, Yeum CH, Chang IY, et al. Activating of ATP-dependent $\mathrm{K}+$ channels comprised of K(ir) 6.2 and SUR 2B by PGE2 through $\mathrm{EP} 2$ receptor in cultured interstitial cells of Cajal from murine small intestine. Cell Physiol Biochem 2006;18:187-198.

29. Pluja L, Yokoshiki H, Sperelakis N. Evidence for presence of ATPsensitive $\mathrm{K}^{+}$channels in rat colonic smooth muscle cells. Can J Physiol Pharmacol 1998;76:1166-1170.

30. Jin X, Malykhina AP, Lupu F, Akbarali HI. Altered gene expression and increased bursting activity of colonic smooth muscle ATP-sensitive $\mathrm{K}^{+}$channels in experimental colitis. Am J Physiol Gastrointest Liver Physiol 2004;287:G274-G285.

31. Jun JY, Kong ID, Koh SD, et al. Regulation of ATP-sensitive $\mathrm{K}^{+}$ channels by protein kinase $\mathrm{C}$ in murine colonic myocytes. Am J Physiol Cell Physiol 2001;281:C857-C864.

32. Poggioli R, Benelli A, Arletti R, Cavazzuti E, Bertolini A. $\mathrm{K}^{+}$channel openers delay intestinal transit and have antidiarrheal activity. Eur J Pharmacol 1995;287:207-209.

33. Kito Y, Suzuki H. Properties of pacemaker potentials recorded from myenteric interstitial cells of Cajal distributed in the mouse small intestine. J Physiol 2003;553(Pt 3):803-818.

34. O'Rourke B. Evidence for mitochondrial $\mathrm{K}^{+}$channels and their role in cardioprotection. Circ Res 2004;94:420-432.

35. Hwang SJ, Blair PJ, Britton FC, et al. Expression of anoctamin 1/TMEM16A by interstitial cells of Cajal is fundamental for slow wave activity in gastrointestinal muscles. J Physiol 2009;587(Pt 20):4887-4904.

36. Lembo AJ, Johanson JF, Parkman HP, Rao SS, Miner PB Jr, Ueno R. Long-term safety and effectiveness of lubiprostone, a chloride channel (ClC-2) activator, in patients with chronic idiopathic constipation. Dig Dis Sci 2011;56:2639-2645.

37. O'Brien CE, Anderson PJ, Stowe CD. Use of the chloride channel activator lubiprostone for constipation in adults with cystic fibrosis: a case series. Ann Pharmacother 2010;44:577-581.

38. Kinard TA, Satin LS. An ATP-sensitive $\mathrm{Cl}^{-}$channel current that is activated by cell swelling, cAMP, and glyburide in insulin-secreting cells. Diabetes 1995;44:1461-1466.

39. Koh SD, Dick GM, Sanders KM. Small-conductance $\mathrm{Ca}^{2+}$-dependent $\mathrm{K}^{+}$channels activated by ATP in murine colonic smooth muscle. Am J Physiol 1997;273(6 Pt 1):C2010-C2021.

40. Gil V, Gallego D, Grasa L, Martin MT, Jimenez M. Purinergic and nitrergic neuromuscular transmission mediates spontaneous neuronal activity in the rat colon. Am J Physiol Gastrointest Liver Physiol 2010;299:G158-G169.

41. Klemm MF, Lang RJ. Distribution of $\mathrm{Ca}^{2+}$-activated $\mathrm{K}^{+}$channel (SK2 and SK3) immunoreactivity in intestinal smooth muscles of the guinea-pig. Clin Exp Pharmacol Physiol 2002;29:18-25.

42. Rechavi G, Rivella S. Regulation of iron absorption in hemoglobinopathies. Curr Mol Med 2008;8:646-662.

43. Vergara C, Latorre R, Marrion NV, Adelman JP. Calcium-activated potassium channels. Curr Opin Neurobiol 1998;8:321-329.

44. Yamane S, Kanno T, Nakamura H, Fujino H, Murayama T. Hydrogen sulfide-mediated regulation of contractility in the mouse ileum with electrical stimulation: roles of L-cysteine, cystathionine beta-synthase, and $\mathrm{K}^{+}$channels. Eur J Pharmacol 2014;740:112-120.

45. Gribkoff VK, Starrett JE Jr, Dworetzky SI. The pharmacology and molecular biology of large-conductance calcium-activated (BK) potassium channels. Adv Pharmacol 1997;37:319-348.

46. Wellman GC, Nelson MT. Signaling between SR and plasmalemma in smooth muscle: sparks and the activation of $\mathrm{Ca}^{2+}$-sensitive ion channels. Cell Calcium 2003;34:211-229.

47. Brenner R, Perez GJ, Bonev AD, et al. Vasoregulation by the beta1 subunit of the calcium-activated potassium channel. Nature 2000; 407:870-876.

48. Semenov I, Wang B, Herlihy JT, Brenner R. BK channel beta1-subunit regulation of calcium handling and constriction in tracheal smooth muscle. Am J Physiol Lung Cell Mol Physiol 2006;291: L802-L810.

49. Kanthesh BM, Sandle GI, Rajendran VM. Enhanced $\mathrm{K}^{+}$secretion in dextran sulfate-induced colitis reflects upregulation of large conductance apical $\mathrm{K}^{+}$channels (BK; Kcnma1). Am J Physiol Cell Physiol 2013;305:C972-C980.

50. Hagen BM, Bayguinov O, Sanders KM. Beta 1-subunits are required for regulation of coupling between $\mathrm{Ca}^{2+}$ transients and $\mathrm{Ca}^{2+}$-activated $\mathrm{K}^{+}(\mathrm{BK})$ channels by protein kinase $\mathrm{C}$. Am J Physiol Cell Physiol 2003;285:C1270-C1280.

51. Semenov I, Wang B, Herlihy JT, Brenner R. BK channel beta1 subunits regulate airway contraction secondary to M2 muscarinic acetylcholine receptor mediated depolarization. J Physiol 2011;589: 1803-1817.

52. Suzuki Y, Yamamura H, Ohya S, Imaizumi Y. Caveolin-1 facilitates 
the direct coupling between large conductance $\mathrm{Ca}^{2+}$-activated $\mathrm{K}^{+}$ (BKCa) and $\mathrm{Cav1.2} \mathrm{Ca}^{2+}$ channels and their clustering to regulate membrane excitability in vascular myocytes. J Biol Chem 2013;288:36750-36761.

53. Nardi A, Olesen SP. BK channel modulators: a comprehensive overview. Curr Med Chem 2008;15:1126-1146.

54. Hedley PL, Jorgensen P, Schlamowitz S, et al. The genetic basis of long QT and short QT syndromes: a mutation update. Hum Mutat 2009;30:1486-1511.

55. Wegener JW, Schulla V, Koller A, Klugbauer N, Feil R, Hofmann F. Control of intestinal motility by the $\mathrm{Ca}(\mathrm{v}) 1.2 \mathrm{~L}$-type calcium channel in mice. FASEB J 2006;20:1260-1262.

56. Lee HT, Kim BJ. Trimebutine as a modulator of gastrointestinal motility. Arch Pharm Res 2011;34:861-864.

57. Gribkoff VK, Starrett JE Jr, Dworetzky SI, et al. Targeting acute is- chemic stroke with a calcium-sensitive opener of maxi-K potassium channels. Nat Med 2001;7:471-477.

58. Koh SD, Sanders KM. Stretch-dependent potassium channels in murine colonic smooth muscle cells. J Physiol 2001;533:155-163.

59. Baker SA, Hennig GW, Han J, Britton FC, Smith TK, Koh SD. Methionine and its derivatives increase bladder excitability by inhibiting stretch-dependent $\mathrm{K}^{+}$channels. Br J Pharmacol 2008;153: 1259-1271.

60. Koh SD, Monaghan K, Sergeant GP, et al. TREK-1 regulation by nitric oxide and cGMP-dependent protein kinase. An essential role in smooth muscle inhibitory neurotransmission. J Biol Chem 2001; 276:44338-44346.

61. Park KJ, Baker SA, Cho SY, Sanders KM, Koh SD. Sulfur-containing amino acids block stretch-dependent $\mathrm{K}^{+}$channels and nitrergic responses in the murine colon. Br J Pharmacol 2005;144:1126-1137. 